\title{
Campylobacter jejuni isolates in Finnish patients differ according to the origin of infection
}

\author{
Benjamin Feodoroff ${ }^{*}$, Patrik Ellström² ${ }^{2}$,Heidi Hyytiäinen ${ }^{3}$, Seppo Sarna ${ }^{4}$, Marja-Liisa Hänninen ${ }^{3}$, Hilpi Rautelin ${ }^{1,2,5}$
}

\begin{abstract}
Background: Campylobacter jejuni is a significant cause of bacterial enteritis worldwide. Very little is known about the pathogenicity mechanisms and virulence factors of this important enteropathogen. C. jejuni isolates from 166 Finnish patients, collected from July to December in 2006, were studied for the presence of putative virulence factors and susceptibility to antimicrobials. Isolates were tested for production of $\gamma$-glutamyltransferase (GGT) as well as the presence of genes ceuE, cgtB, ciaB, cj0486, pldA, virB11, wlaN, and the gene cluster cdtABC. Bacterial characteristics were compared to information on foreign travel history as well as information on the course and the symptoms of disease obtained from questionnaires returned by patients.

Results: Except for one domestic isolate, antimicrobial resistance was only detected in isolates of foreign origin. Univariate analyses showed association between bloody stools and both GGT production ( $p=0.025)$ and the presence of $c g t B(p=0.034)$. Multivariate analysis verified that GGT production was more prevalent in domestic isolates $(p<0.0001)$, while the genes cj0486 ( $<$ < 0.0001) and ceuE $(p<0.0001)$ were associated with $C$. jejuni isolates of foreign origin.
\end{abstract}

Conclusions: The results indicate that imported and domestic C. jejuni isolates differ significantly in several aspects from each other.

\section{Background}

Campylobacter jejuni is a leading cause of bacterial enteritis in developed countries and the most commonly reported zoonosis in the European Union [1]. C. jejuni colonizes the gastrointestinal tract of many animals including poultry and wild birds, cattle, pigs, cat and dog. Eating undercooked poultry has been shown to be a risk factor for campylobacteriosis also in Finland [2], however, poultry is colonized with Campylobacter to a significantly lower extent than in many other countries [3]. Epidemiological studies using serotyping and genotyping methods have revealed a high diversity among $C$. jejuni from different sources in Finland and the risk factors for human Campylobacter infection may vary according to the geographical area and even with age $[4,5]$.

Although the genomes of several $C$. jejuni strains have been sequenced [6-8], very little is still known about the pathogenicity mechanisms and the virulence factors of

\footnotetext{
* Correspondence: benjamin.feodoroff@helsinki.fi

'Department of Bacteriology and Immunology, Haartman Institute, University of Helsinki, Haartmaninkatu 3, PO Box 21, FIN-00014, Helsinki, Finland
} Full list of author information is available at the end of the article this common enteropathogen [9]. The acute Campylobacter infection is often self-limited but in severe cases antimicrobial and hospital treatment may be needed. The reasons why certain patients develop a more serious acute infection or late sequelae of the disease are not understood.

Several studies have searched for the presence of putative virulence factors among Campylobacter isolates of human and animal origin but only few studies have been able to show an association between certain bacterial factors and the outcome of human Campylobacter infection. Genes studied have usually included those suggested to have a role in adhesion, colonization, invasion and toxin production. The plasmid-associated gene virB11 [10], as well as the genes ciaB (Campylobacter invasive antigen B) $[11,12]$, and cj0486 encoding a putative sugar transporter [13] have been suggested to be involved in invasiveness. In addition, pldA encoding outer membrane phospholipase A [14], and ceuE encoding enterochelin uptake binding protein [15] have been studied. The genes $\operatorname{cgtB}[16]$ and wlaN [17] are involved in the biosynthesis of lipooligosaccharide (LOS), which 
may show ganglioside-mimicking structures important for the triggering of Guillain-Barré syndrome, an acute peripheral polyneuropathy, after $C$. jejuni infection [18]. Cytolethal distending toxin (CDT, encoded by the gene cluster $c d t A B C$ ) has been present in most of the tested isolates [19] but its role in the outcome of the disease still remains uncertain. Likewise, a recent report showed $\gamma$-glutamyl transpeptidase (GGT, encoded by the gene $g g t$ ) to have a role in the persistent colonization of the avian gut [20], but its importance in the course of human campylobacteriosis is not known.

We have recently demonstrated that $C$. jejuni isolates of domestic origin and those highly susceptible for ciprofloxacin were associated with a more severe form of enteritis characterized by bloody stools [21]. Our aim in the present study was to reveal other bacterial factors that may affect the outcome of the $C$. jejuni infection in a well-characterized clinical material including both infections acquired abroad or in Finland. For that purpose, we analyzed 166 clinical isolates of $C$. jejuni for the production of GGT and the presence of the genes virB11, ciaB, cgtB, wlaN, cj0486, ceuE, pldA and $c d t A B C$.

\section{Methods}

\section{Patients and Campylobacter isolates}

A total of 166 patients with sporadic stool culture-verified C. jejuni infection (no other bacterial enteropathogens detected) were included in the present study. Their stool samples were collected from July 1 to December 31, 2006, and they had returned questionnaires including questions concerning travelling abroad within two weeks before the onset of symptoms, the clinical course of the illness and antimicrobial therapy. The patients belonged to a group of 192 persons (originally also including C. coli positive patients), some results of which have earlier been presented [21]. All the isolates were hippurate positive and were stored at $-70^{\circ} \mathrm{C}$ before analyzed.

\section{Susceptibility testing}

The minimal inhibitory concentration (MIC) values of ciprofloxacin (Bayer, Leverkusen, Germany), doxycycline (Orion Pharma, Espoo, Finland) and erythromycin (Amdipharm Ltd, Dublin, Ireland) were determined by an agar dilution method according to the CLSI guidelines [22]. Mueller-Hinton agar (Oxoid, Basingstoke, UK) plates supplemented with defibrinated sheep blood (5\%) and the control strain C. jejuni ATCC 33560 were used. The susceptibility of the isolates was interpreted according to CLSI [23]. The results of susceptibility of the isolates to ciprofloxacin have been published earlier [21].

\section{PFGE typing}

PFGE analysis was performed for 75 (all 40 domestic and all 35 travel-associated isolates collected in July, as the prevalence of cases per month was the highest during this month) isolates as described earlier [3,24]. Isolate was considered to represent a new type when PFGE KpnI profile differed by at least one band.

\section{$\gamma$-Glutamyl transpeptidase activity}

In the first phase we studied the presence or absence of ggt gene as described in our previous study [25]. All isolates positive for the gene were further analyzed for the production of GGT. Qualitative detection of GGT activity was achieved as described previously for Helicobacter pylori [26]. Briefly, approximately $10^{9}$ bacteria were suspended in a reagent containing $50 \mathrm{mM}$ Tris (pH 8.25), $1.5 \mathrm{mM} \mathrm{L- \gamma -}$ glutamyl-carboxyl-3 nitro-4 anilide and $50 \mathrm{mM}$

glycylglycine. The mixture was incubated for $1 \mathrm{~h}$ at $37^{\circ} \mathrm{C}$. Cleavage of the substrate by $\gamma$-glutamyl transpeptidase turned the mixture yellow in color.

\section{PCR detection of other putative $C$. jejuni virulence factors}

DNA was extracted from C. jejuni isolates using the following protocols. Bacteria $\left(10^{8} \mathrm{CFU}\right)$ were harvested from blood agar plates (Columbia agar II containing $8 \%$ $\mathrm{vol} / \mathrm{vol}$ whole horse blood), dissolved in $500 \mu \mathrm{l}$ of $\mathrm{ddH}_{2} \mathrm{O}$ and incubated in a boiling water bath for $10 \mathrm{~min}$. Cell debris was removed by centrifugation at $18000 \mathrm{~g}$ for 2 min. For some isolates DNA was extracted using either a method utilizing guanidium thiocyanate [27], DNeasy Blood \& Tissue kit (Qiagen) or Wizard Genomic DNA Purification Kit (Promega, UK) according to the manufacturer's instructions. Successful extraction of template C. jejuni DNA from each isolate was confirmed by PCR amplification of the house keeping gene $g l y A$. The presence of the gene $g l y A$ and the putative virulence factors virB11, ciaB, cgtB, wlaN, pldA, ceuE, Cj0486 as well as the $c d t A B C$ operon were determined by PCR using the primers listed in Table 1 . The reaction mixture was prepared in $1 \times$ AmpliTaq Gold 360 buffer with $1.25 \mathrm{U}$ of AmpliTaq Gold 360 polymerase (Applied Biosystems, USA), $200 \mu \mathrm{M}$ dNTP (Fermentas, Germany), $0.2 \mu \mathrm{M}$ of each primer (Eurogentec, Ougrée, Belgium) and $5 \mu \mathrm{l}$ of template DNA in a total volume of $25 \mu \mathrm{l}$.

The PCR reactions started with a denaturation step at $95^{\circ} \mathrm{C}$ for $10 \mathrm{~min}$. The cycling conditions were 25 cycles of $95^{\circ} \mathrm{C}$ for $30 \mathrm{~s}$, annealing temperatures (Table 1) for $30 \mathrm{~s}$ and $72^{\circ} \mathrm{C}$ for $60 \mathrm{~s}(120 \mathrm{~s}$ for $c d t A B C)$. For virB11 and $g l y A$ a touch down protocol was run with 5 cycles at $53^{\circ} \mathrm{C}, 5$ cycles at $52^{\circ} \mathrm{C}$ and 15 cycles at $51^{\circ} \mathrm{C}$. The reactions ended with an additional extension step at $72^{\circ} \mathrm{C}$ for $7 \mathrm{~min}$. DNA extracted from C. jejuni NCTC 11168 was used as a positive control for the genes $c d t A B C$, wlaN and Cj0486 and DNA from C. jejuni 81176 served as a positive control for all other virulence genes. A PCR reaction without added template was used as a negative control. 
Table 1 Primer sequences, annealing temperatures and PCR product sizes for the putative virulence factors studied

\begin{tabular}{|c|c|c|c|c|c|}
\hline Gene & Primers & Sequence $\left(5^{\prime}-3^{\prime}\right)$ & Annealing temp $\left({ }^{\circ} \mathrm{C}\right)$ & Product (bp) & Reference \\
\hline glyA & $\begin{array}{l}\text { Gly-Fw } \\
\text { Gly-rev }\end{array}$ & $\begin{array}{l}\text { GAGTTAGAGCGTCAATGTGAAGG } \\
\text { AAACCTCTGGCAGTAAGGGC }\end{array}$ & $53-51$ & 1052 & {$[36]$} \\
\hline virB11 & $\begin{array}{l}\text { VirB-232 } \\
\text { VirB-701 }\end{array}$ & $\begin{array}{l}\text { TCTTGTGAGTTGCCTTACCCCTTIT } \\
\text { CCTGCGTGTCCTGTGTATTACCC }\end{array}$ & 53 & 494 & {$[35]$} \\
\hline ceuE & $\begin{array}{l}\text { CeuE405F } \\
\text { CeuE405R }\end{array}$ & $\begin{array}{l}\text { GATAAAGTCGTTGGCGTTCC } \\
\text { GCGAGATTGGAGGACCAAAGG }\end{array}$ & 60 & 405 & * \\
\hline $\mathrm{ciaB}$ & $\begin{array}{l}\text { ciaB355F } \\
\text { ciaB355R }\end{array}$ & $\begin{array}{l}\text { CAGAAGGAGAAATTTGTGAGC } \\
\text { ATATCCCATTCTAATGCCACC }\end{array}$ & 58 & 355 & * \\
\hline pldA & $\begin{array}{l}\text { pldA-84fwd } \\
\text { pld-981rev }\end{array}$ & $\begin{array}{l}\text { AAGCTTATGCGTIITI } \\
\text { TATAAGGCTTTCTCCA }\end{array}$ & 45 & 913 & {$[35]$} \\
\hline Cj0486 & $\begin{array}{l}\text { Cj0486fwd } \\
\text { Cj0486rev }\end{array}$ & $\begin{array}{l}\text { GATAGAGCATTAAATTGGGATG } \\
\text { CCTATAAAGCCATACCAAGCC }\end{array}$ & 58 & 1263 & [13] \\
\hline wlaN & $\begin{array}{l}\text { wlaN-DL } 39 \\
\text { Cj1139cF }\end{array}$ & $\begin{array}{l}\text { TTAAGAGCAAGATATGAAGGTG } \\
\text { TGCTGGGTATACAAAGGTTGTG }\end{array}$ & 60 & 434 & {$[17,37]$} \\
\hline $\operatorname{cgt} \mathrm{B}$ & $\begin{array}{l}\text { wlaN-DL } 39 \\
\text { cgtBrev }\end{array}$ & $\begin{array}{l}\text { TTAAGAGCAAGATATGAAGGTG } \\
\text { GCACATAGAGAACGCTACAA }\end{array}$ & 56 & 563 & [17] \\
\hline$c d t A B C$ & $\begin{array}{l}\text { LYA-F } \\
\text { MII-R }\end{array}$ & $\begin{array}{l}\text { CTITATGCATGTTCTTCTAAATTT } \\
\text { GTTAAAGGTGGGGTATAATCATT }\end{array}$ & 55 & 2111 & [38] \\
\hline
\end{tabular}

*Personal communication: Rafal Gierczyński, National Institute of Public Health, Warsaw, Poland.

\section{Statistical analyses}

Statistical analyses were performed with GraphPad Prism version 4.03 (GraphPad Software, San Diego, CA, USA) and PASW Statistics 18 (SPSS for Windows, Rel. 18.0.2. 2010. SPSS Inc, Chicago, IL, USA). The $\chi^{2}$ test and Fisher's exact test were used for comparison of categorical variables. Multivariate analyses were performed with stepwise binary logistic regression models. All tests were two-sided, and a p-value $<0.05$ was considered to be significant.

The study was approved by the Ethics Committee of the Hospital District of Helsinki and Uusimaa.

\section{Results}

Of the 166 cases of C. jejuni infection in the study 126 were acquired abroad and 40 were acquired in Finland. Resistance to erythromycin ( 4 isolates) and resistance to doxycycline (59 isolates) were only detected in isolates of foreign origin. All except one of the isolates of domestic origin were susceptible for ciprofloxacin whereas 83/126 $(66 \%)$ of isolates of foreign origin were resistant to ciprofloxacin, as published earlier [21]. Prevalence of the putative virulence markers among the isolates according to MICs to ciprofloxacin and doxycycline, respectively, is presented in Table 2. GGT-production was associated with susceptibility to ciprofloxacin and doxycycline in the univariate analysis. On the other hand, both ciprofloxacin- and doxycycline-resistant isolates were more likely than the susceptible ones to harbor the genes cj0486 and ceuE (Table 2).

Contingency tables were also used to assess whether the presence of putative virulence factors correlated with clinical data. In the univariate analysis (Table 3),
GGT production and the presence of the gene $\operatorname{cgt} B$ were associated with bloody stools. In addition, isolates lacking the ceuE gene were associated with hospitalization, as $8 / 24(33 \%)$ of the patients infected with ceuEnegative isolates were hospitalized, compared to $21 / 139$ $(15 \%)$ of those with ceuE-positive isolates $(\mathrm{p}=0.031)$. GGT production was strongly associated with infections acquired in Finland as compared to infections from abroad. On the other hand, the genes cj0486 and ceuE were markedly more common among isolates of foreign origin. Of all the domestic isolates, 34/40 (85\%) showed at least one of the following characteristics; GGT-production, lack of $c j 0486$ or absence of $c e u E$ whereas the number of foreign isolates was 60 (48\%), respectively $(\mathrm{p}<0.0001)$. A total of $69 / 126(55 \%)$ of the imported isolates, but only $7 / 40$ (18\%) of the domestic isolates were positive for both cj0486 and ceuE ( $\mathrm{p}<0.0001)$. The significant findings in the univariate model were controlled with a multivariate analysis to assess whether some of the variables were independently associated with each other. GGT-production was independently associated with domestic infections, and the genes cj0486 and ceuE were independently associated with imported infections, respectively (Table 4). Although bloody diarrhea was significantly associated with both GGT-production and the presence of $c g t B$ in the univariate analysis, this factor could not be further analyzed with a multivariate analysis as the proportion of missing data in the questionnaires regarding this specific finding was too high (28\%).

PFGE analysis with KpnI digested samples revealed that among the 40 domestic isolates, a total of 32 PFGE types were identified indicating a high diversity. 
Table 2 Contingency table results for antimicrobial susceptibility and putative virulence markers among 166 C. jejuni isolates

\begin{tabular}{|c|c|c|c|c|c|c|c|c|c|}
\hline \multirow[t]{2}{*}{ MIC values } & \multicolumn{9}{|c|}{ Putative virulence factor } \\
\hline & $\begin{array}{l}\text { GGT- } \\
\text { production }\end{array}$ & virB11 & $c i a B$ & cgtB & $w l a N$ & cj0486 & $c e u E$ & pldA & $\operatorname{cdt} A B C$ \\
\hline $\begin{array}{l}\text { Ciprofloxacin MIC } \leq 1 \\
(82 / 166) *\end{array}$ & $\begin{array}{l}20 / 82 \\
(p=0.001) \S\end{array}$ & $1 / 82$ & $81 / 82$ & $16 / 82$ & $17 / 82$ & $31 / 82$ & $62 / 82$ & $52 / 82$ & $69 / 82$ \\
\hline $\begin{array}{l}\text { Ciprofloxacin MIC } \geq 4 \\
(84 / 166) \dagger\end{array}$ & $5 / 84$ & $3 / 84$ & $83 / 84$ & $15 / 84$ & $22 / 84$ & $\begin{array}{l}50 / 84 \\
(p=0.0051)\end{array}$ & $\begin{array}{l}80 / 84 \\
(p=0.0003)\end{array}$ & $49 / 84$ & $62 / 84$ \\
\hline $\begin{array}{l}\text { Doxycycline MIC } \leq 2 \\
(102 / 166) *\end{array}$ & $\begin{array}{l}22 / 102 \\
(p=0.0032) \S\end{array}$ & $1 / 102$ & $101 / 102$ & $22 / 102$ & $20 / 102$ & $40 / 102$ & $82 / 102$ & $59 / 102$ & $82 / 102$ \\
\hline $\begin{array}{l}\text { Doxycycline MIC } \geq 4 \\
(64 / 166) \neq\end{array}$ & $3 / 64$ & $3 / 64$ & $63 / 64$ & $9 / 64$ & $19 / 64$ & $\begin{array}{l}41 / 64 \\
(p=0.0018) \#\end{array}$ & $\begin{array}{l}60 / 64 \\
(p<0.0001) \#\end{array}$ & $42 / 64$ & $49 / 64$ \\
\hline $\begin{array}{l}\text { No. positive isolates } \\
\text { (\%) }\end{array}$ & $\begin{array}{l}25 / 166 \\
(15 \%)\end{array}$ & $\begin{array}{l}4 / 166 \\
(2.4 \%)\end{array}$ & $\begin{array}{l}164 / 166 \\
(99 \%)\end{array}$ & $\begin{array}{l}31 / 166 \\
(19 \%)\end{array}$ & $\begin{array}{l}39 / 166 \\
(23 \%)\end{array}$ & $\begin{array}{l}81 / 166 \\
(49 \%)\end{array}$ & $\begin{array}{l}142 / 166 \\
(86 \%)\end{array}$ & $\begin{array}{l}101 / 166 \\
(61 \%)\end{array}$ & $\begin{array}{l}131 / 166 \\
(79 \%)\end{array}$ \\
\hline
\end{tabular}

*interpreted as susceptible, tinterpreted as resistant, finterpreted as resistant or intermediate (5 isolates with MIC 4 mg/L), §associated with susceptible isolates, Ilassociated with resistant isolates, \#associated with resistant or intermediate isolates

Furthermore, all the 35 isolates of foreign origin analyzed had different PFGE profiles, which did not overlap with those of domestic isolates. Thus, the isolates were highly diverse and did not seem to have a common source.

\section{Discussion}

We recently showed that bloody stools were more common among patients infected with $C$. jejuni isolates of domestic origin and those highly susceptible for ciprofloxacin [21]. C. jejuni isolates of Finnish origin have even earlier been shown to differ significantly from those of foreign origin as being almost exclusively susceptible for ciprofloxacin $[28,29]$. In the present study, we further analyzed possible differences between $C$. jejuni isolates acquired in Finland and those from abroad and screened for the presence of certain putative virulence markers. Significant differences were detected as GGT production was independently associated with infection of domestic origin and the isolates of foreign origin significantly more often harbored the genes cj0486 and ceuE, findings also verified with a multivariate analysis.

GGT is an enzyme present in both bacteria and eukaryotes. It has a role in glutathione and glutamine metabolism in C. jejuni [30]. The presence of ggt has been shown to vary among C. jejuni isolates $[20,31]$ and we

Table 3 Characteristics of 166 patients and putative virulence factors present in the respective C. jejuni isolates

\begin{tabular}{|c|c|c|c|c|c|c|c|c|c|}
\hline \multirow[t]{2}{*}{ Clinical characteristics } & \multicolumn{9}{|c|}{ Putative virulence factor } \\
\hline & $\begin{array}{l}\text { GGT- } \\
\text { production }\end{array}$ & virB11 & ciaB & $\operatorname{cgtB}$ & $w l a \mathrm{~N}$ & cj0486 & CeuE & pldA & $c d t A B C$ \\
\hline Female sex $(99 / 166)$ & $17 / 99$ & 3/99 & $98 / 99$ & $19 / 99$ & $23 / 99$ & $52 / 99$ & $85 / 99$ & $62 / 99$ & $78 / 99$ \\
\hline $\begin{array}{l}\text { Underlying disease } \\
(38 / 162)\end{array}$ & $9 / 38$ & $3 / 38$ & $37 / 38$ & $10 / 38$ & $9 / 38$ & $18 / 38$ & $32 / 38$ & $23 / 38$ & $31 / 38$ \\
\hline $\begin{array}{l}\text { Domestic infection } \\
(40 / 166)\end{array}$ & $\begin{array}{l}16 / 40 \\
(p<0.0001) *\end{array}$ & $1 / 40$ & 40 & $9 / 40$ & $8 / 40$ & $7 / 40$ & $26 / 40$ & $25 / 40$ & $34 / 40$ \\
\hline $\begin{array}{l}\text { Infection from abroad } \\
126 / 166)\end{array}$ & $9 / 126$ & $3 / 126$ & $124 / 126$ & $22 / 126$ & $31 / 126$ & $\begin{array}{l}74 / 126 \\
(p<0.0001)+\end{array}$ & $\begin{array}{l}116 / 126 \\
(p<0.0001)+\end{array}$ & $76 / 126$ & $97 / 126$ \\
\hline Vomiting (41/156) & $8 / 41$ & $1 / 41$ & $40 / 41$ & $8 / 41$ & $9 / 41$ & $17 / 41$ & $34 / 41$ & $25 / 41$ & $32 / 41$ \\
\hline Fever (136/156) & $20 / 136$ & $4 / 136$ & $134 / 136$ & $27 / 136$ & $30 / 136$ & $66 / 136$ & $115 / 136$ & $82 / 136$ & $104 / 136$ \\
\hline Bloody stools (21/119) & $\begin{array}{l}6 / 21 \\
(p=0.025)\end{array}$ & $1 / 21$ & 21 & $\begin{array}{l}8 / 21 \\
(p=0.034)\end{array}$ & $3 / 21$ & $9 / 21$ & $17 / 21$ & $16 / 21$ & $18 / 21$ \\
\hline $\begin{array}{l}\text { Long-lasting }(\geq 10 \mathrm{~d}) \\
\text { diarrhea }(42 / 161)\end{array}$ & $6 / 42$ & $1 / 42$ & 42 & $\begin{array}{l}12 / 42 \\
(p=0.051)\end{array}$ & $7 / 42$ & $18 / 42$ & $35 / 42$ & $24 / 42$ & $31 / 42$ \\
\hline Hospitalization (29/163) & $3 / 29$ & $1 / 29$ & 29 & $7 / 29$ & $8 / 29$ & $15 / 29$ & $\begin{array}{l}21 / 29 \\
(p=0.031) \neq\end{array}$ & $19 / 29$ & 23/29 \\
\hline No. positive isolates (\%) & $\begin{array}{l}25 / 166 \\
(15 \%)\end{array}$ & $\begin{array}{l}4 / 166 \\
(2.4 \%)\end{array}$ & $\begin{array}{l}164 / 166 \\
(99 \%)\end{array}$ & $\begin{array}{l}31 / 166 \\
(19 \%)\end{array}$ & $\begin{array}{l}39 / 166 \\
(23 \%)\end{array}$ & $\begin{array}{l}81 / 166 \\
(49 \%)\end{array}$ & $\begin{array}{l}142 / 166 \\
(86 \%)\end{array}$ & $\begin{array}{l}101 / 166 \\
(61 \%)\end{array}$ & $\begin{array}{l}131 / 166 \\
(79 \%)\end{array}$ \\
\hline
\end{tabular}

*associated with domestic infection, tassociated with infection from abroad, fthe absence of ceuE associated with hospitalization 
Table 4 Multivariate analysis showing independent association between origin of infection and certain C. jejuni markers

\begin{tabular}{llll}
\hline Virulence marker & OR & 95\% Confidence interval & p-value \\
\hline GGT* $^{*}$ & 8.67 & $3.43-21.91$ & $<0.0001$ \\
\hline cj0486† & 6.71 & $2.75-16.39$ & $<0.0001$ \\
\hline ceuEt & 6.71 & $2.67-16.95$ & $<0.0001$ \\
\hline
\end{tabular}

*associated with domestic infection, tassociated with imported infection

recently demonstrated that ggt was common among human and chicken $C$. jejuni isolates but significantly less common among bovine isolates [25]. GGT activity in $C$. jejuni has been suggested to affect the persistent colonization of the avian gut [20] and in a mouse model for C. jejuni it was shown to enhance colonization [30]. In our study, GGT-production was present in $15 \%$ of the isolates and associated with bloody diarrhea in the univariate analysis, although the latter, due to a lack of data available, could not be further analyzed in a multivariate analysis. Interestingly, the domestic $C$. jejuni isolates were able to produce GGT significantly more often than the imported isolates, a finding also verified by the multivariate analysis. PFGE typing of all domestic isolates verified the sporadic nature of the domestically acquired infections confirming also that GGT production was not linked with a certain genotype.

The gene cj0486, encoding a putative sugar transporter and suggested to be related to invasiveness [13], as well as the gene $c e u E$, encoding a transport protein for uptake of the siderophore enterochelin [32] were detected in $49 \%$ and $86 \%$ of the isolates in the present study, respectively, in line with some other reports [19]. Although their presence was not associated with the outcome of the disease, interestingly they were significantly more often found among isolates of foreign than among those of domestic origin. Furthermore, the isolates lacking $c e u E$ seemed to cause infections requiring hospital treatment, but this finding was not verified by the multivariate analysis. In addition to the typing of all domestic isolates, PFGE typing of travel-associated isolates from July indicated that almost all patients had unique genotypes and none of the studied characteristics was linked with a genotype. Travel-associated isolates originated from a total of 36 different countries.

Only few studies have been promising in trying to show correlation between putative virulence factors or the characteristics of $C$. jejuni and the outcome of the disease. Of the different $C$. jejuni markers studied in the present report, GGT production and the presence of $\operatorname{cgt} B$ were associated with bloody stools in the univariate analysis, but the other putative virulence factors did not correlate with any specific clinical findings. The $B-1,3$ galactosyltransferase gene $c g t B$ in the LOS gene clusters
$\mathrm{A}$ and $\mathrm{B}$ involved in the biosynthesis of ganglioside-like LOS $[16,17]$ also showed a trend of being associated with longer-lasting diarrhea. C. jejuni LOS gene clusters A, B and C have even earlier been associated not only with a more severe outcome of the disease as characterized by bloody stools and longer duration of diarrhea but also with the development of post-infectious complications [33]. However, in the present study, the other ß-1,3 galactosyltransferase gene wlaN, expressed in the LOS gene cluster $C$ [34] was not associated with any clinical characteristics. The gene $c i a B$ has been suggested to be involved in invasiveness $[11,12]$ and thus, could be needed for the development of the disease. Indeed, all except two of the 166 isolates in our study were $c i a B$ positive, which is in line with earlier reports $[19,35]$. The presence of another putative virulence factor the gene pldA, encoding phospholipase A [14], was detected in the present study to a somewhat lower extent (61\%) as compared to other reports (91-100\%) $[19,35]$, and did not correlate with the clinical outcome of the disease. As CDT and virB11 were concerned, our results supported those of others showing CDT activity in the great majority [19] but the presence of virB11 in only a tiny proportion $[13,19]$ of clinical C. jejuni isolates. Thus, it seems very unlikely that these particular markers would play a role in the diversity of the outcome of the human disease.

\section{Conclusions}

In conclusion, we suggest for the first time that GGT production could be a marker associated with a more severe outcome of $C$. jejuni infection as characterized by bloody stools, however, additional work is needed to clarify the importance of this finding. Furthermore, to the best of our knowledge, this is the first report to describe the presence of putative virulence markers significantly and independently to differ between $C$. jejuni isolates of foreign and domestic origin. Whether this also reflects the different sources of $C$. jejuni infections locally in Finland remains to be studied.

\section{Acknowledgements}

The study was supported by a grant from the Academy of Finland (ELVIRA) and a fellowship grant from Emil and Ragna Börjesson memorial fund (Patrik Ellström). The skilled technical assistance of Marko Haverinen and Anna Nilsson is gratefully acknowledged.

\section{Author details}

'Department of Bacteriology and Immunology, Haartman Institute, University of Helsinki, Haartmaninkatu 3, PO Box 21, FIN-00014, Helsinki, Finland.

2Department of Medical Sciences, University of Uppsala, S-75185 Uppsala, Sweden. ${ }^{3}$ Department of Food and Environmental Hygiene, University of Helsinki, PO Box 66, FIN-00014, Helsinki, Finland. ${ }^{4}$ Department of Public Health, University of Helsinki, Mannerheimintie 172, PO Box 41, FIN-00014, Helsinki, Finland. ${ }^{5}$ Helsinki University Central Hospital Laboratory, Helsinki, Finland. 


\section{Authors' contributions}

BF participated in the design of the study, collected and analyzed data performed statistical analyses and prepared the draft manuscript. PE participated in the selection of virulence factors, performed and supervised some PCR experiments. HH performed the PFGE and conducted some PCR experiments. SS provided expertise in statistical analyses. MLH participated in the design of the study and supervised the performance of some experiments. HR participated in the design of the project, coordinated and supervised the study and helped to draft the manuscript. All authors provided ideas and comments on the draft manuscript and approved the final manuscript.

\section{Competing interests}

The authors declare that they have no competing interests.

Received: 3 December 2010 Accepted: 20 December 2010 Published: 20 December 2010

\section{References}

1. The community summary report on trends and sources of zoonoses, zoonotic agents and foodborne outbreaks in the European Union in 2008. The EFSA Journal 2010, 1496.

2. Schönberg-Norio D, Takkinen J, Hänninen ML, Katila M, Kaukoranta S, Mattila L, Rautelin H: Swimming and Campylobacter infections. Emerg Infect Dis 2004, 10:1474-1477.

3. Hänninen ML, Perko-Mäkelä P, Pitkälä A, Rautelin H: A three-year study of Campylobacter jejuni genotypes in humans with domestically acquired infections and in chicken samples from the Helsinki area. J Clin Microbiol 2000, 38:1998-2000.

4. Kärenlampi R, Rautelin H, Schönberg-Norio D, Paulin L, Hänninen ML: Longitudinal study of Finnish Campylobacter jejuni and C. coli isolates from humans, using multilocus sequence typing, including comparison with epidemiological data and isolates from poultry and cattle. Appl Environ Microbiol 2007, 73:148-155.

5. Schönberg-Norio D, Sarna S, Hänninen ML, Katila M, Kaukoranta S, Rautelin H: Strain and host characteristics of Campylobacter jejuni infections in Finland. Clin Microbiol Infect 2006, 12:754-760.

6. Parkhill J, Wren BW, Mungall K, Ketley JM, Churcher C, Basham D, Chillingworth T, Davies RM, Feltwell T, Holroyd S, Jagels K, Karlyshev AV, Moule S, Pallen MJ, Penn CW, Quail MA, Rajandream MA, Rutherford KM van Vliet AH, Whitehead S, Barrell BG: The genome sequence of the foodborne pathogen Campylobacter jejuni reveals hypervariable sequences. Nature 2000, 403:665-668

7. Fouts DE, Mongodin EF, Mandrell RE, Miller WG, Rasko DA, Ravel J, Brinkac LM, DeBoy RT, Parker CT, Daugherty SC, Dodson RJ, Durkin AS, Madupu R, Sullivan SA, Shetty JU, Ayodeji MA, Shvartsbeyn A, Schatz MC, Badger $\mathrm{JH}$, Fraser CM, Nelson KE: Major structural differences and novel potential virulence mechanisms from the genomes of multiple Campylobacter species. PloS Biol 2005, 3:e15.

8. Hofreuter D, Tsai J, Watson RO, Novik V, Altman B, Benitez M, Clark C, Perbost C, Jarvie T, Du L, Galán JE: Unique features of a highly pathogenic Campylobacter jejuni strain. Infect Immun 2006, 74:4694-4707, Erratum in: Infect Immun 2007, 75(1):542.

9. Haddad N, Marce C, Magras C, Cappelier JM: An overview of methods used to clarify pathogenesis mechanisms of Campylobacter jejuni. [Review] [177 refs]. J Food Protect 2010, 73:786-802.

10. Bacon DJ, Alm RA, Burr DH, Hu L, Kopecko DJ, Ewing CP, Trust TJ, Guerry P: Involvement of a plasmid in virulence of Campylobacter jejuni 81-176. Infect Immun 2000, 68:4384-90.

11. Konkel ME, Kim BJ, Rivera-Amill V, Garvis SG: Identification of proteins required for the internalization of Campylobacter jejuni into cultured mammalian cells. Adv Exp Med Biol 1999, 473:215-24.

12. Rivera-Amill V, Kim BJ, Seshu J, Konkel ME: Secretion of the virulenceassociated Campylobacter invasion antigens from Campylobacter jejuni requires a stimulatory signal. J Infect Dis 2001, 183:1607-16.

13. Fearnley C, Manning G, Bagnall M, Javed MA, Wassenaar TM, Newell DG: Identification of hyperinvasive Campylobacter jejuni strains isolated from poultry and human clinical sources. J Med Microbiol 2008, 57:570-580.

14. Grant KA, Belandia IU, Dekker N, Richardson PT, Park SF: Molecular characterization of pldA, the structural gene for a phospholipase A from
Campylobacter coli, and its contribution to cell-associated hemolysis. Infect Immun 1997, 65:1172-1180.

15. Richardson PT, Park SF: Enterochelin acquisition in Campylobacter coli: characterization of components of a binding-protein-dependent transport system. Microbiology 1995, 141:3181-3191.

16. Gilbert M, Brisson JR, Karwaski MF, Michniewicz J, Cunningham AM, Wu Y, Young NM, Wakarchuk WW: Biosynthesis of ganglioside mimics in Campylobacter jejuni OH4384. Identification of the glycosyltransferase genes, enzymatic synthesis of model compounds, and characterization of nanomole amounts by $600-\mathrm{mhz}(1) \mathrm{h}$ and (13)c NMR analysis. J Biol Chem 2000, 275:3896-3906.

17. Linton D, Gilbert M, Hitchen PG, Dell A, Morris HR, Wakarchuk WW, Gregson NA, Wren BW: Phase variation of a beta-1,3 galactosyltransferase involved in generation of the ganglioside GM1-like lipo-oligosaccharide of Campylobacter jejuni. Mol Microbiol 2000, 37:501-514.

18. van Doorn PA, Ruts $L$, Jacobs BC: Clinical features, pathogenesis, and treatment of Guillain-Barre syndrome [Review] [158 refs]. Lancet Neurol 2008, 7:939-950.

19. Talukder KA, Aslam M, Islam Z, Azmi IJ, Dutta DK, Hossain S, Nur-E-Kamal A, Nair GB, Cravioto A, Sack DA, Endtz HP: Prevalence of virulence genes and cytolethal distending toxin production in Campylobacter jejuni isolates from diarrheal patients in Bangladesh. J Clin Microbiol 2008, 46:1485-1488.

20. Barnes $I H$, Bagnall MC, Browning DD, Thompson SA, Manning G, Newell DG: Gamma-glutamyl transpeptidase has a role in the persistent colonization of the avian gut by Campylobacter jejuni. Microb Pathog 2007, 43:198-207.

21. Feodoroff FB, Lauhio AR, Sarna SJ, Hänninen ML, Rautelin HI: Severe diarrhoea caused by highly ciprofloxacin-susceptible Campylobacter isolates. Clin Microbiol Infect 2009, 15:188-192.

22. Clinical and Laboratory Standards Institute/NCCLS. Performance for antimicrobial susceptibility testing: fifteenth informational supplement. CLSI/NCCLS document M100-S15. Wayne, PA: CLSI 2005.

23. Clinical and Laboratory Standards Institute. Methods for antimicrobial dilution and disk susceptibility testing of infrequently isolated or fastidious bacteria; approved guideline. CLSI document M45-A. Wayne, PA: CLSI 2006.

24. Maslow JN, Slutsky AM, Arbeit RD: Application of pulsed-field gel electrophoresis to molecular epidemiology. In Diagnostic molecular microbiology: principles and applications. Edited by: Persing DH, Smith TF, Tenover FC, White TJ. Washington: American Society for Microbiology: 1993:563-72.

25. Gonzalez M, Hakkinen M, Rautelin H, Hänninen ML: Bovine Campylobacter jejuni strains differ from human and chicken strains in an analysis of certain molecular genetic markers. Appl Environ Microbiol 2009, 75:1208-1210.

26. Shibayama K, Kamachi K, Nagata N, Yagi T, Nada T, Doi Y, Shibata N, Yokoyama $K$, Yamane $K$, Kato H, linuma Y, Arakawa Y: A novel apoptosisinducing protein from Helicobacter pylori. Mol Microbiol 2003, 47:443-451.

27. Pitcher DG, Saunders NA, Owen RJ: Rapid extraction of bacterial genomic DNA with guanidium thiocyanate. Lett Appl Microbiol 1989, 8:151-156.

28. Rautelin H, Vierikko A, Hänninen ML, Vaara M: Antimicrobial susceptibilities of Campylobacter strains isolated from Finnish subjects infected domestically or from those infected abroad. Antimicrob Agents Chemother 2003, 47:102-105.

29. Schönberg-Norio D, Hänninen ML, Katila ML, Kaukoranta SS, Koskela M, Eerola E, Uksila J, Pajarre S, Rautelin H: Activities of telithromycin, erythromycin, fluoroquinolones, and doxycycline against Campylobacter strains isolated from Finnish subjects. Antimicrob Agents Chemother 2006, 50:1086-1088.

30. Hofreuter D, Novik V, Galán JE: Metabolic diversity in Campylobacter jejuni enhances specific tissue colonization. Cell Host Microbe 2008, 4:425-433.

31. Ahmed IH, Manning G, Wassenaar TM, Cawthraw S, Newell DG: Identification of genetic differences between two Campylobacter jejuni strains with different colonization potentials. Microbiology 2002, 148:1203-1212.

32. Park SF, Richardson PT: Molecular characterization of a Campylobacter jejuni lipoprotein with homology to periplasmic siderophore-binding proteins. J Bacteriol 1995, 177:2259-2264.

33. Mortensen NP, Kuijf ML, Ang CW, Schiellerup P, Krogfelt KA, Jacobs BC, van Belkum A, Endtz HP, Bergman MP: Sialylation of Campylobacter jejuni lipo- 
oligosaccharides is associated with severe gastro-enteritis and reactive arthritis. Microbes Infect 2009, 11:988-994.

34. Godschalk PC, Heikema AP, Gilbert M, Komagamine T, Ang CW, Glerum J, Brochu D, Li J, Yuki N, Jacobs BC, van Belkum A, Endtz HP: The crucial role of Campylobacter jejuni genes in anti-ganglioside antibody induction in Guillain-Barre syndrome. J Clin Invest 2004, 114:1659-1665.

35. Datta S, Niwa H, Itoh K: Prevalence of 11 pathogenic genes of Campylobacter jejuni by PCR in strains isolated from humans, poultry meat and broiler and bovine faeces. J Med Microbiol 2003, 52:345-348.

36. Dingle KE, Colles FM, Wareing DR, Ure R, Fox AJ, Bolton FE, Bootsma HJ, Willems RJ, Urwin R, Maiden MC: Multilocus sequence typing system for Campylobacter jejuni. J Clin Microbiol 2001, 39:14-23.

37. Wassenaar TM, Wagenaar JA, Rigter A, Fearnley C, Newell DG, Duim B: Homonucleotide stretches in chromosomal DNA of Campylobacter jejuni display high frequency polymorphism as detected by direct PCR analysis. FEMS Microbiol Lett 2002, 212:77-85.

38. Bang DD, Nielsen EM, Scheutz F, Pedersen K, Handberg K, Madsen M: PCR detection of seven virulence and toxin genes of Campylobacter jejuni and Campylobacter coli isolates from Danish pigs and cattle and cytolethal distending toxin production of the isolates. J Appl Microbiol 2003, 94:1003-1014.

doi:10.1186/1757-4749-2-22

Cite this article as: Feodoroff et al:: Campylobacter jejuni isolates in Finnish patients differ according to the origin of infection. Gut Pathogens 2010 2:22.

\section{Submit your next manuscript to BioMed Central} and take full advantage of:

- Convenient online submission

- Thorough peer review

- No space constraints or color figure charges

- Immediate publication on acceptance

- Inclusion in PubMed, CAS, Scopus and Google Scholar

- Research which is freely available for redistribution

Submit your manuscript at www.biomedcentral.com/submit
Biomed Central 